\title{
Native and Non-native English Speaking Teachers' Teaching Styles and Their Effect on Their EFL Saudi Students' Achievement and Enjoyment of Learning English at Taif University
}

\author{
Nasrah Mahmoud Ismaiel ${ }^{1}$ \\ ${ }^{1}$ English Language Center, Deanship of Supportive Studies, Taif University, Saudi Arabia \\ Correspondence: Nasrah Mahmoud Ismaiel, English Language Center, Deanship of Supportive Studies, Taif \\ University, Saudi Arabia. E-mail: n.ismaiel@tu.edu.sa
}

\author{
Received: May 27, 2017 Accepted: July 14, 2017 Online Published: September 25, 2017 \\ doi:10.5539/ijel.v7n6p148 URL: http://doi.org/10.5539/ijel.v7n6p148
}

\begin{abstract}
The present research is going to assess the discrepancies between native and non-native instructors working at Taif University. The subjects have been 609 Saudi men and women EFL learners presenting themselves in a great English language plan at the preparatory year Science, Humanities and Health at Taif University. Moreover, 51 teachers (20) males and (31) females who are teaching staff members of the Taif University English Language Centre (TUELC) participated during the research. The research followed a descriptive analytical method. The Conti (1990) Principles of Adult Learning Scales (PALS) was used. Learning English Enjoyment questionnaire (LEEQ) that was developed by the researcher was used, too. Primary areas of investigation were teaching styles, students' achievement and students' enjoyment of learning English. Collectively, results provide some strong evidence that show a positive connection between native English speaking teachers' styles and the students' achievement and enjoyment. The effect of instruction experience, like the periods of instructing was considered in the present research. In addition, native and nonnative instructors who speak English are regarded also various in such domains as instruction strategies in the classes, levels of teaching tactical effectiveness.
\end{abstract}

Keywords: native as well as non-native English speaking instructors, instruction styles, enjoyment, gender, college students

\section{Introduction}

In Saudi Arabia, EFL teachers can be divided into two different categories: native subjects of the English language (NESTs) and non-native subjects of English (NNESTs). So knowing the discrepancies between native and non-native subjects of English teaching styles are important to designers of curricula to know which styles will be preferred by the EFL students and also which are more effective corroborated by the students' positive achievement. Furthermore, it is important to those teachers who teach English to Saudi students to know which teaching styles will be more beneficial for them. Moreover, teachers should be provided access to the preferred teaching training of teaching styles and its applications in the classroom.

It is significant for instructors to realize the characteristics of the learners with whom they will work because teachers' understanding of the nature of their students and their learning process will help them to achieve the educational goals that they set for their students. In teaching English, teachers need to increase attention to strategies that enhance students thinking and to build symbolic relationships among English concepts. Students, who each have different individual differences and cognitive development levels, need different teaching styles. So the teachers should meet the students' different learning styles. To know teachers' instructing methods can create a discrepancy in how instructors categorize their courses, how they tackle with the subjects, and how well their learners accomplish in the instruction content (Conti, 1989, p. 88). Finally, knowing the differences between native and non-native English speakers' teaching styles is important as these styles affect their students' achievement and enjoyment.

\section{Method}

For the teaching styles questionnaire, 51 teachers (20) males and (31) females who are teaching staff members of the Taif University English Language Centre (TUELC) participated at the time of the study. Teachers' age ranged from 23 to $67(\mathrm{M}=36.313, \mathrm{SD}=10.056)$. The highest percentage of respondents held a Bachelor's degree. 31 held 
Bachelor, 19 held Master and 1 doctoral.

For the English learning enjoyment questionnaire 609 students of PYP Science, Humanities and Health took part in the study. Students' age ranged from 17-29 years $(\mathrm{M}=19.349, \mathrm{SD}=1.065)$.

\section{Research Question}

The present research is to specify if differences exist among teaching style preferences of TUELC teachers and selected variables. The first cause for this study is that learners' achievement is the most notable factor in the educational process. Educators should be aware what the factors are that can affect it. Knowles (1970) reported that the instructor is the most significant variable in the course for learner learning. The second reason is that the researcher is working in the English language Centre, Taif University, where many native foreign English speaking instructors are working, so she would like to find out what the differences are among those teachers in their teaching styles. Or in other words, what are the types of the teaching styles that native English speaking teachers prefer and how much do these various styles have an effect on their students' achievement.

Finally Students' enjoyment of learning English is another important factor that has a big effect on their achievement, especially because the English language, according to cultural beliefs and educational curricula in Saudi Arabia, does not focus very much on learning English, so the students have to be self-motivated in order to learn English. However the negative cultural bias towards learning English language is in the process of changing with the increased use of technology and the travelling of Saudi students abroad in the interest of gaining higher education. So students' enjoyment of learning English plays a notable section in contributing to Saudi learners to achieve English and increasing their motivation and achievement. This researcher hopes to discover the differences in students' enjoyment of learning English according to the variation of teaching styles of the native and foreign English speaking instructors.

Nevertheless, little focus has been given to the influences of the native and foreign English speaking instructors' teaching styles on their students' achievement and enjoyment. This study also strives to cover such a gap in the previous works and investigate the effects the effects of the native and foreign English speaking instructors' teaching styles on their students' achievement and enjoyment with respect to learning English in the Saudi EFL context.

The study questions for this investigation addressed the different instruction methods of native and foreign English speaking instructors (NNESTs) and their influence on learners' enjoyment and therefore their rate of success in learning English.

1). Explain the instruction methods of native and foreign English speaking instructors as determined by the Principles of Adult Learning Scale (PALS)?

2). To what extent is there a connection between instruction methods and the demographic variables of age, gender, country and the periods of instructing experience?

3). Are there any connections between the instructors' methods and their students' achievement?

4). Are there any differences between the females and males teaching styles?

\subsection{Research Hypothesis}

1). There exist discrepancies between male and female instructors in their instruction methods.

2). There are positive relationships between years of instruction experience, and instruction methods.

3). There are significant effects for streams and gender and their interaction on the English learning enjoyment.

4). There exist discrepancies between learners of native English speaking instructors and learners of foreign English speaking instructors in the enjoyment of English learning.

5). There are discrepancies between NESTs and NNESTs on instruction methods.

6). There exist discrepancies between native English speaking instructors' learners and foreign English speaking instructors' learners in their acquisition.

\subsection{Significance of the Study}

The present research is helpful to the domains of instructing English as a foreign language and adult instruction by giving the attitudes of Saudi EFL learners studying English in elementary year plans. Instructors and curriculum makers may discover this study helpful for enhancing curriculum structure and course methodology connected to the language student tactics applied by Saudi EFL learners. 


\subsection{The Aim of the Study}

The aim of this research was to determine the instruction methods ELC native and foreign English speaking instructors in University of Taif, Saudi Arabia. It aims at achieving two major goals: first, the research aims at drawing attention to how teachers' teaching styles impact students' achievement. Secondly, the study intends to assess the connection between the teachers' teaching styles and their students' enjoyment of learning English.

\section{Literature Review}

\subsection{Native and Non-Native English speaking Instructing Styles and Students' Achievement}

Richards, Platt, \& Platt, (1992) in their Dictionary of Language Teaching \& Applied Linguistics characterized the native language as the language which someone learned in the early age. In the similar vein, Phillipson (1992) observed native subjects as the pattern of "standard grammar and vocabulary which teaching materials and sound recordings seek to reanimate," he further believed that their talent of "demonstrating fluent, idiomatically appropriate language, in appreciating the cultural connotations of the language" (p. 194). Phillipson (1992) astutely showed the significant relation between a language and the cultural facets that language implies. Native subjects not only possess the realization of language, but they also possess enough realization of the cultural facets within the language which makes them capable of speaking "natively." Their linguistic and social knowledge and the "native" accent have a notable role in language instructing tools.

Instruction method alludes to the obvious features presented by an instructor that are continuing from a context to another without reference to the content (Conti, 1989). To make a difference in student achievement, teachers must first realize their own instruction method and then perform classroom tasks related to that method while making a context convincing in relation to the various learning methods of their learners. To realize the instructing method of the instructors can make a discrepancy in how instructors set their courses, how they treat the students, and how well their subjects do in the realizing content (Conti, 1989, p. 88). While the results of Alghofaili \& Elyas (2017) showed that instructors' native quality and presuppositions have no notable efficacy on the EFL Saudi learners' acquisition methods. And instead they attributed success in teaching to some other characteristics such as teachers' competence and experience, instructors sharing the learners' L1 play proper roles in the EFL acquisition process, instructors accent and teacher's personality. Corresponding to Mahboob (2004) and (Walkinshaw \& Oanh, 2014), NNESTs can be viewed as better at instructing reading, writing, grammar, and language-learning tasks because of their social realization and metalinguistic capability.

In the domain of English language instruction, some research have been done to assess the discrepancies between native and non-native language instructors concerning pedagogical good as well as bad points.(Samimy \& Brutt-Griffler, 1999; Arva \& Medgyes, 2000). Arva \& Medgyes (2000) found out the discrepancies that are shown in three facets of instructions: own application of the language, overall thinking, and thinking about instructing the language. Concerning the higher command in English, native English-speaking instructors in their research inclined to deliver fewer exams and assignment and preferred free tasks, like work in teams or pairs, and the attitudes which had a great deal of instruments. In the opposite side, their nonnative subjects preferred more supervised tasks, like a translation task or practices, and got a more instructed attitude that needed a book and more assignment. Native instructors were viewed to be less competent to the instruction and less focused to learners' acquisition, while nonnative instructors were more astute and more adamant in instructing and had more realistic tackles with the learners' instruction. Regarding linguistic foci in instruction, native instructors wanted to concentrate such aspects as fluency, verbal tasks or colloquial registers, while nonnative instructors concentrated more on precision, grammar laws or formal registers.

Samimy \& Brutt-Griffler (1999) noted the same discrepancies in instructing behaviors discovered in Arva \& Medgyes's research. The subjects in Samimy \& Brutt-Griffler's research believed that native-speaking instructors applied real English in communicating with learners, got various methods and tactics, and accentuated on interaction rather than test preparation. Nonnative speaking instructors believed to be cognizant of psychological facets of acquisition, more effective in instruction, but concentrating on the test preparation.

Moussu (2010) mentioned that previous studies have generally reported that native subjects of the English can be considered superior to their non-native subjects of English counterparts in the areas of pronunciation, vocabulary, idiomatic expressions, and Western cultures, whereas non-native subjects of the same language have been found to have a better understanding of grammar, teaching methods, and local education-related systems and cultures. Medgyes (1994) reported that most of the fore in subjects of English language approved the existence of discrepancies between native subjects of English language and non-native subjects of English in terms of their teaching behaviors, and noted a close relationship between native subjects of English and foreign subjects differences in their teaching practices and in their perceived linguistic competence. 


\subsection{Enjoyment and Teaching Styles}

Early research on enjoyment is found in a study by Piaget (1962). He recommended that a baby in the game repeats his demeanor not in any further strive to acquire or assess but for the pleasure of learning it. Pleasure is a mode of feeling or psychological joy (Kuppens, 2008). Davis (1982) gave a causal approach of pleasure. The essential supposition is that an object of pleasure makes the speaker to have joy by causing concurrent attitudes that satisfy desires regarding the experience per se. The rate of pleasure can be characterized as a section of the learners' joy attributable to the object of pleasure. Ainley \& John (2011) reported that pleasure is essential to connections between interest in knowledge, content of knowledge, and learners' delivered present and future works.

A number of former research believed that the experience of pleasure is a central element in specifying one's attitude for and continued attempt in task contexts (Kremer, Trew, \& Ogle, 1997; Wankel, 1993). Pleasure and work are essential and preconditions of children's playful acquisition experiences (Malone, 1980; Prensky, 2001; Heidegger, 1990; Montessori, 1965). They all are needed for informal achievement and can be a benefit to real acquisition as well. Pleasure and funny works are famous to be influential in children's growth (Clements, 1995), both controlling and deepening the process of acquisition (Resnick, Bruckman, \& Martin, 1999) as well as making the engagement easy and the attitude understandable. So, I selected them as the essential dependent variables assessed in this research. Scherer's study (1986) "revealed a relationship between teacher's enjoyment of teaching and student's enjoyment in learning process" (p. 12).

Prensky (2001) showed that a mixture of twelve factors make games fascinating. Fun and pleasure can be considered the most significant aspects of all these twelve factors. Al-Shara (2015) mentioned that students' enjoyment can increased by focusing on operating learning resources in instructing and instigating learners who have low acquisition rates in the tasks. Nevertheless, he pointed out that the effect of learners' role on learners' pleasure was the least influenced element for learners who have lower acquisition level. Many studies pointed out absence or lack of enjoyment during the learning process affect negatively on the students' achievement and leads to failure to learn. In addition, student's enjoyment motivates him/her to learn (Kunter, Tsai, Klusmann, Brunner, Krauss, \& Baumert, 2008).

\section{Instrumentation}

\subsection{Pilot Study}

The pilot study included two different samples of teachers and students. For the English learning enjoyment questionnaire the pilot research was accomplished applying the t-test style. The sample group numbered forty-two male and female students. The sample age ranged from $18-22$ years $(\mathrm{M}=19.071, \mathrm{Sd}=.808$. The students responded well to the survey questionnaire.

While the sample group numbered forty-nine male and female teachers. The Sample age ranged from 23-67 years $(\mathrm{M}=38.62, \mathrm{SD}=10.14)$. The teachers participating are from different countries; they have been divided into two parts: native English subjects and foreign English subjects. They responded well to the survey questionnaire. The specific objectives for the pilot testing were: (1) to assure that the terminology and goal of every test have been realized by each subject. (2) To have recommendations to enhance the survey. (3) To specify the rate of period needed to complete the survey. (4) To determine the probable issues which may happen as the survey was designed to the learners. (5) To check the validity and reliability of the questionnaires.

\subsection{Learning English Enjoyment Questionnaire}

The Learning English Enjoyment questionnaire of 26 items was prepared and developed by the researcher. It is considered a self-reported measure. This researcher adopted learning-related enjoyment subscale of 10 items of the Accomplishment Feelings Survey that was designed by Pekrun, Goetz and Derry, 2005 and modified those items to be suitable for learning English as those items were written concerning learning, in general. The researcher generated 16 other items from personal teaching experience. So, the questionnaire became of 26 items and the final edition of the survey was revised and reviewed by the three English native speakers.

Enjoyment in this study was operationally defined as the students' ratings of their enjoyment and three relevant subscales on a one to five Likert style scale.

\subsection{Psychometric Conditions of the Learning English Enjoyment Questionnaire in the Present Study}

According to the case-total correlation two elements $(4 \& 11)$ were deleted, so it became 24 items instead of 26. To achieve trustworthy and prestigious responds from the learners and as the learners are foreign majors, the scholar translated the Learning English Enjoyment questionnaire (LEEQ) into Arabic language as the sample 
students of the research are native speakers of Arabic. (See Appendix B). Based on the factor analysis items 9, 10, 18,19 were also deleted. The final version of this questionnaire consisted of 20 items.

\subsection{Case Validity and Inner Consistency for the Learning English Enjoyment Survey}

The corrected case-total correlation rated from 0.39 to $0.70(\mathrm{p}<0.01)$, recommending enough case prestige. The amended case-Subscale 1 (Enjoying to acquire new knowledge in English) correlation ranged from 0.35 to 0.70 $(\mathrm{p}<0.01)$. For Subscale 2(Motivational aspects/ affectional aspects) the correlation rated from 0.35 to 0.61 ( $\mathrm{p}<$ 0.01). For Subscale 3(having pleasure of taking part in English) the correlation rated from 0.45 to $0.65(\mathrm{p}<0.01)$. For Subscale 4 (Enjoy doing English activities in the classroom) the correlation rated from 0.33 to 0.58 ( $\mathrm{p}<$ 0.01 ). The correlation among elements rated from 0.40 to 0.79 but the correlation among elements and the total mark rated from 0.74 to 0.86 . ( $\mathrm{p}<0.05$ to $\mathrm{p}<0.01$ ).

The inner consistency was high for the whole survey $(\alpha=0.90)$, as well as for the minor scale $1(\alpha=0.82)$, minor scale $2(\alpha=0.72)$, minor scale $3(\alpha=0.77)$, minor scale $4(\alpha=0.68)$ the average total mark was 74.95 (S.D. $=$ 12.08). The average for minor scale 1 was 27.83 (S.D. $=4.37$ ), for minor scale 2 was 14.21 (S.D. $=3.17$ ), for minor scale 3 was 19.07 (S.D. $=3.78$ ) and for minor scale 4 was 13.83 (S.D. $=3.43$ ).

\subsection{Factor Analyses: Learning English Enjoyment Questionnaire}

Principal-components factor analyses using varimax rotation were performed. The factor analysis yielded four-element solution for the marks in the "Learning English Enjoyment questionnaire" information. The four extracted elements considered below.

\subsection{Element Assessment: Learning English Enjoyment Questionnaire}

The four achieved elements considered for 61.78 of the whole variance. Equamax with Kaiser Normalization was then used. Table 1 shows a synopsis of the outcomes of the elements assessment of the "Learning English Enjoyment" information. The element loadings of every case in this part on the four circulated elements and tools, and standard deviations of the cases that were delivered in (see Appendix B). The questionnaire was designed according to a 5-point Likert-scale that ranged from indicating that the statement is strongly disagree through 5 the statement is strongly disagree.

\subsection{Teaching Styles Questionnaire}

\subsubsection{Principles of Adult Learning Scales (PALS)}

The researcher translated the Teaching styles questionnaire into Arabic as the students are non-English major and to get reliable responses from the students. The Arabic kind of the survey was debated and observed by skilled Arabic instructors to avoid any kind of vagueness in the wording of the survey and to ensure content validity.

Conti (1990) designed the Principles of Adult Learning Scales (PALS) that is a tol created to help persons in knowing their instructing method (Appendix B). This tool can help instructors to "pinpoint their specific classroom practices and relate them to what is known about teaching and learning" (p. 75). This 44-item instrument assesses the rate with which one exercises instructing/acquiring rules that are defined in the adult works. Good marks on the PALS show support for a student-centered attitude to instruction. Low grades show support for instructor-centered theory. The grades in the average range uncover a mixed attitude that draws on actions from every extreme. In addition to measuring overall tendencies toward either learner or teacher centeredness, and instructor's educational views on the following seven sub scores are provided: (a) student-Centered tasks, (b) enliven education, (c) connecting to practice, (d) evaluating learner requirements, (e) Climate Structure, (f) Taking part in the acquisition Process, and (g) Flexibility for Individual growth (Conti, 1985, p. 9).

\subsubsection{Psychometric Conditions of the Teaching styles Questionnaire}

Based on the item -total correlation for factors 16 items were deleted; 3, 6, 7, 9, 16, 18, 19, 21, 22, 26, 27, 28, 32, $37,40 \& 42$. So, the questionnaire became 28 instead of 44 items. To achieve a trustworthy and prestigious responds from the learners and as the learners are foreign experts, the scholar translated the Teaching methods survey into Arabic, as the sample students of the research are native speakers of Arabic (See Appendix A).

\section{Item validity and internal consistency for Teaching Styles Questionnaire}

The corrected item-total correlation ranged from 0.36 to $0.72(\mathrm{p}<0.01)$, suggesting adequate item validity. The corrected item-Subscale 1 (Learner-Centered Activities) correlation ranged from 0.39 to 0.79 ( $\mathrm{p}<0.01$ ), for Subscale 2 (Personalizing Instruction) the correlation ranged from 0.35 to $0.60(\mathrm{p}<0.01)$, for Subscale 3 (Relating to Experience) the correlation ranged from 0.32 to $0.41(\mathrm{p}<0.01)$, for Subscale 4 (Assessing Student 
Needs) the correlation ranged from 0.35 to $0.47(\mathrm{p}<0.01)$, but for Subscale 5 (Climate Building) the correlation ranged from 0.45 to $0.65(\mathrm{p}<0.01)$, Subscale 6 (Participation in the Learning Process) the correlation ranged from 0.34 to $0.52(\mathrm{p}<0.01)$, Subscale 7 (Flexibility for Personal Development) the correlation ranged from 0.44 to $0.74(\mathrm{p}<0.01)$ suggesting adequate item validity. While the correlation between factors ranged from 0.29 to 0.65. and between factors and total score ranged from 0.45 to 0.89 . ( $\mathrm{p}<0.05$ to $\mathrm{p}<0.01$ ).

The inner consistency was high for the whole survey $(\alpha=0.90)$, as well as for minor scale $1(\alpha=0.80)$, minor scale $2(\alpha=0.70)$, minor scale $3(\alpha=0.52)$, minor scale $4(\alpha=0.57)$ minor scale $5(\alpha=0.67)$, minor scale 6 ( $\alpha$ $=0.66)$, and for minor scale $7(\alpha=0.61)$. The average Total grade has been106.82 (S.D. $=23.36)$. The mean for minor scale 1 was 30.14 (S.D. $=8.48)$, for minor scale 2 has been 25.44 (S.D. $=5.81)$, for minor scale 3 has been 10.36 (S.D. $=3.08$ ) for minor scale 4 was 6.86 (S.D. $=2.42)$, for minor scale 5 was 11.24 (S.D. $=4.11$ ), for minor scale 6 has been 9.54 (S.D. $=3.09$ ) and for minor scale 7 has been 13.10 (S.D. $=3.87$ ).

\section{Results}

6.1 Hypothesis 1, There Are Significant Effects for Streams and Gender and Their Interaction (3× 2) On the English Learning Enjoyment

Table 1. Gender and stream Crosstabulation

\begin{tabular}{llllll}
\hline & & Stream & & & Total \\
& & Health & Science & humanity & \\
\hline \multirow{2}{*}{ Gender } & Male & 146 & 56 & 72 & 274 \\
& Female & 140 & 118 & 77 & 335 \\
\hline Total & & 286 & 174 & 149 & 609 \\
\hline
\end{tabular}

Table 2. Multivariate tests

\begin{tabular}{|c|c|c|c|c|c|c|c|}
\hline Effect & & Value & $\boldsymbol{F}$ & Hypothesis df & Error df & Sig. & $\eta 2$ \\
\hline \multirow[t]{3}{*}{ Intercept } & Pillai's Trace & .951 & 2929.815 & 4.000 & 600.000 & .000 & .951 \\
\hline & Wilks’ Lambda & .049 & 2929.815 & 4.000 & 600.000 & .000 & .951 \\
\hline & Roy's Largest Root & 19.532 & 2929.815 & 4.000 & 600.000 & .000 & .951 \\
\hline \multirow[t]{2}{*}{ Stream } & Pillai's Trace & .090 & 7.095 & 8.000 & 1202.000 & .000 & .045 \\
\hline & Roy's Largest Root & .092 & 13.752 & 4.000 & 601.000 & .000 & .084 \\
\hline \multirow[t]{3}{*}{ Gender } & Pillai's Trace & .032 & 4.924 & 4.000 & 600.000 & .001 & .032 \\
\hline & Wilks' Lambda & .968 & 4.924 & 4.000 & 600.000 & .001 & .032 \\
\hline & Hotelling's Trace & .033 & 4.924 & 4.000 & 600.000 & .001 & .032 \\
\hline \multirow{2}{*}{ Steam * Gender } & Hotelling's Trace & .046 & 3.421 & 8.000 & 1198.000 & .001 & .022 \\
\hline & Roy's Largest Root & .038 & 5.719 & 4.000 & 601.000 & .000 & .037 \\
\hline
\end{tabular}

Table 2 shows that through using Multivariate Tests (Pillai's Trace, Wilks' Lambda, Hotelling's Trace and Roy's Largest Root), $\boldsymbol{F}$ is significant. For the stream $(F(8,1200)=7,213=P<0.000)$, Wilk's $=0.91$ and partial Eta Square $=0.046$. For gender, $F(4,600)=4.924=P<0.001)$, Wilk's $=0.97$, and partial Eta Square $=0.032$. For the interaction between stream and gender $F(8,1200),=3.410=P<0.001)$ Wilk's $=.96$, and partial Eta Square $=$ 0.022 . 
Table 3. MANOVA for differences between gender and streams and their interactions on enjoyment questionnaire scores

\begin{tabular}{|c|c|c|c|c|c|c|c|}
\hline Source & Dependent Variable & Type III Sum of Squares & Df & Mean Square & $\mathbf{F}$ & Sig. & $\eta 2$ \\
\hline \multirow[t]{5}{*}{ Stream } & Enjoying to acquire new knowledge in English & 1784.106 & 2 & 892.053 & 26.047 & .000 & .080 \\
\hline & Motivational aspects/ affectional aspects & 244.450 & 2 & 122.225 & 9.804 & .000 & .031 \\
\hline & Enjoying participation in English & 298.450 & 2 & 149.225 & 8.728 & .000 & .028 \\
\hline & Enjoy doing English activities in the classroom. & 341.692 & 2 & 170.846 & 10.633 & .000 & .034 \\
\hline & Total score & 8682.544 & 2 & 4341.272 & 17.920 & .000 & .056 \\
\hline \multirow[t]{5}{*}{ Gender } & Enjoying to acquire new knowledge in English & 14.850 & 1 & 14.850 & .434 & .510 & .001 \\
\hline & Motivational aspects/ affectional aspects & 55.628 & 1 & 55.628 & 4.462 & .035 & .007 \\
\hline & Enjoying participation in English & 73.906 & 1 & 73.906 & 4.323 & .038 & .007 \\
\hline & Enjoy doing English activities in the classroom. & 191.707 & 1 & 191.707 & 11.931 & .001 & .019 \\
\hline & Total score & 1139.374 & 1 & 1139.374 & 4.703 & .030 & .008 \\
\hline Stream & *Enjoying to acquire new knowledge in English & 692.092 & 2 & 346.046 & 10.104 & .000 & .032 \\
\hline \multirow[t]{4}{*}{ Gender } & Motivational aspects/ affectional aspects & 178.228 & 2 & 89.114 & 7.148 & .001 & .023 \\
\hline & Enjoying participation in English & 292.004 & 2 & 146.002 & 8.539 & .000 & .028 \\
\hline & Enjoy doing English activities in the classroom. & 127.310 & 2 & 63.655 & 3.962 & .020 & .013 \\
\hline & Total score & 4530.302 & 2 & 2265.151 & 9.350 & .000 & .030 \\
\hline \multirow[t]{5}{*}{ Error } & Enjoying to acquire new knowledge in English & 20651.706 & 603 & 34.248 & & & \\
\hline & Motivational aspects/ affectional aspects & 7517.165 & 603 & 12.466 & & & \\
\hline & Enjoying participation in English & 10309.735 & 603 & 17.097 & & & \\
\hline & Enjoy doing English activities in the classroom. & 9688.932 & 603 & 16.068 & & & \\
\hline & Total score & 146082.862 & 603 & 242.260 & & & \\
\hline
\end{tabular}

Note. $\eta 2=0.01$ is a very small value, $\eta 2=0.06$ is an average effect, $\eta 2=0.15$ has a strong effect.

Table 3 reveals that there are effects for gender and stream on the students' enjoyment as factors and total score.

There is an effect for streams Health-Science-Humanities) on the students' enjoyment, whereas the total score of students' enjoyment questionnaire is $F(2,606)=17.920, \mathrm{P}<0.000, \eta 2=0.06$. This means that stream has an average effect on the students' enjoyment. For the effects of gender on English learning students' enjoyment, the total score of the students' enjoyment is $\boldsymbol{F}(1.607),=4.703, \mathrm{P}<.03, \eta 2=0.01$. This means that gender has a small effect on students' enjoyment. In addition, the interaction between stream and gender also effect on English learning students' enjoyment as factors and total score $\boldsymbol{F}(2.606),=9.350, \mathrm{P}<.000, \eta 2=0.030)$. And to know the differences among groups according to the academic streams, Scheffe test was used in the following table.

Table 4. Multiple comparisons Scheffe test

\begin{tabular}{llllll}
\hline Enjoyment questionnaire factors & & & Mean Difference (I-J) & Std. Error & Sig. \\
\hline Dependent Variable & (I) stream & (J) stream & & & \\
\hline Enjoying to acquire new knowledge in English & Health & Science & $1.9567^{*}$ & .5627 & .003 \\
& & humanity & $4.1755^{*}$ & .5913 & .000 \\
& Science & humanity & $2.2189^{*}$ & .6532 & .003 \\
\hline Motivational aspects/ affectional aspects & Health & humanity & $1.5850^{*}$ & .3567 & .000 \\
Enjoying participation in English & Health & Science & $.9815^{*}$ & .3975 & .048 \\
& & humanity & $1.6405^{*}$ & .4178 & .000 \\
\hline Enjoy doing English activities in the classroom. & humanity & Health & $1.9103^{*}$ & .4050 & .000 \\
& & Science & $1.1031^{*}$ & .4474 & .049 \\
\hline Total score & Health & Science & $4.4170^{*}$ & 1.4965 & .013 \\
& & humanity & $9.3114^{*}$ & 1.5726 & .000 \\
& Science & humanity & $4.8944^{*}$ & 1.7373 & .019 \\
\hline
\end{tabular}

Note. Based on observed means.* The mean difference is significant at the .05 level.

Table 4 shows that For Factor 1, There exist notable discrepancies between health stream $(\mathrm{M}=27.692, \mathrm{Sd}=5$. $103)$ and science stream $(\mathrm{M}=25.736, \mathrm{Sd}=6.449)$ in favor of health stream. As well as there are significant differences between health stream $(M=27.692, S d=5.103)$ and humanities $(M=23.517, S d=6.757)$ in favor of health. There exist notable discrepancies between science stream and humanities in favor of science. For factor 2, there are significant differences between health stream $(\mathrm{M}=14.0280, \mathrm{SD}=3.355)$ and humanities $(12.443, \mathrm{sd}=$ $3.875)$ in favor of health stream. For factor 3, There exist notable discrepancies between health stream $(\mathrm{M}=$ 
18.573, $\mathrm{Sd}=3.728)$ and science stream $(\mathrm{M}=17.592, \mathrm{Sd}=4.403)$ in favor of health stream. There exist notable discrepancies between health stream and humanities $(16.933, \mathrm{sd}=4.808)$ in favor of health stream.

For factor 4, There exist notable discrepancies between health stream $(\mathrm{M}=14.273, \mathrm{Sd}=3.404)$ and humanities $(12.362, \mathrm{sd}=4.087)$ in favor of health stream. There exist notable discrepancies between humanities science stream $(\mathrm{M}=13.465, \mathrm{Sd}=4.978)$ in favor of science stream. For the total score, There exist notable discrepancies between the total score of the Health stream $(\mathrm{M}=74.566, \mathrm{Sd}=13.650)$ and the total score of science stream $(\mathrm{M}=$ $70.149, \mathrm{Sd}=17.237$ ) in favor of the Health stream. There exist notable discrepancies between the total of the health stream and humanities $(65.255, \mathrm{sd}=17.993)$ in favor of health stream. There exist notable discrepancies between total score of science stream and total score of humanities in favor of science stream.

\subsection{The Differences in Gender for English Learning Enjoyment}

For factor 1, there are significant differences between males $(M=26.438, s d=6.233)$ and females $(M=25.845$, $\mathrm{sd}=6.107)$ in favor of males. For factor 2, there are significant differences between males $(\mathrm{M}=14.699, \mathrm{sd}=3.417)$ and females $(\mathrm{M}=13.329, \mathrm{sd}=3.152)$ in favour of males. For factor 3, there are significant differences between males $(M=19.404, \mathrm{sd}=3.298)$ and females $(M=17.707, \mathrm{sd}=3.958)$ in favor of males. For factor 4 , there exist notable discrepancies between males $(\mathrm{M}=15.0822, \mathrm{sd}=3.310)$ and females $(\mathrm{M}=13.429, \mathrm{sd}=3.305)$ in favor of males. For the total score, there exist notable discrepancies between males $(\mathrm{M}=73.095, \mathrm{SD}=16.591)$, and females $(\mathrm{M}=69.334, \mathrm{SD}=15.842)$, in favor of males.

Table 5. Discrepancies between the students of native English speaking instructors and the students of foreign English speaking instructors in the English learning enjoyment

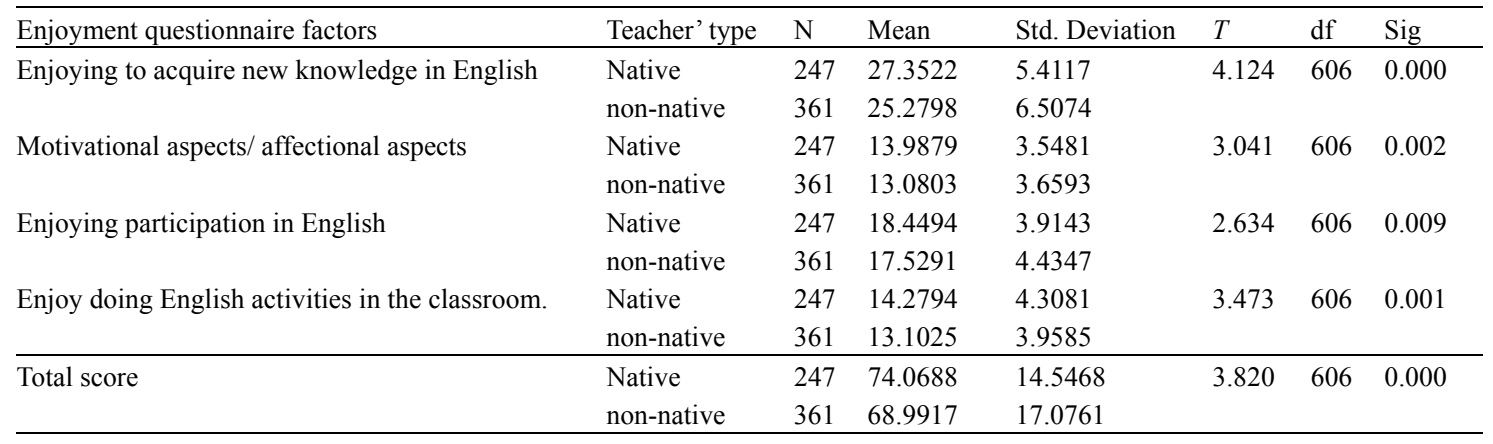

Table 5 indicates that there exist notable discrepancies between the students of native English instructors and the students of foreign English speaking instructors on the English learning enjoyment questionnaire in favor of the students of native English speaking teachers in all factors and total score.

Table 6. Differences between students of native English speaking instructors and students of foreign in the achievement

\begin{tabular}{llllllll}
\hline & Teacher' type & $\mathrm{N}$ & Mean & Std. Deviation & $\mathrm{t}$ & $\mathrm{Df}$ & sig \\
\hline \multirow{2}{*}{ Achievement } & Native & 266 & 77.8308 & 11.3973 & 3.789 & 607 & 0.000 \\
& non-native & 343 & 74.0729 & 12.6839 & & & \\
\hline
\end{tabular}

Table 6 indicates that there exist notable discrepancies between students' achievement of NESTs and NNESTs in favor of students' achievement of native teachers. This is could be explained in the light of native English speaking teachers are more persuasive teachers inside the classroom as the English language their mother tongue. It might be because also focus on Student-centered -approach the teacher centered -approach more than foreign instructors. In addition, English instructors are more interested in using teaching aids inside the classroom those foreign instructors. Native teachers are more encouraging for the students' accomplishments. 
Table 7. The discrepancies between English and foreign English speaking instructors in their instruction styles

\begin{tabular}{llllllll}
\hline Teaching styles questionnaire & Nationality & $\mathbf{N}$ & Mean & Sd. & t & Df & sig \\
\hline Learner centered activities & Native & 20 & 22.650 & 7.220 & 1.878 & 49 & 0.066 \\
& ESL & 31 & 19.032 & 6.3796 & & & \\
Personalizing instruction & Native & 20 & 14.800 & 4.262 & 1.602 & 49 & 0.116 \\
& ESL & 31 & 12.774 & 4.499 & & & \\
Relating to experience & Native & 20 & 8.700 & 3.131 & 1.473 & 49 & 0.147 \\
& ESL & 31 & 7.484 & 2.706 & & & \\
Assessing student needs & Native & 20 & 8.100 & 3.144 & & 49 & 0.058 \\
Climate building & ESL & 31 & 6.613 & 2.319 & & \\
& Native & 20 & 10.400 & 2.891 & & 49 & 0.005 \\
Participation in the learning process & ESL & 31 & 8.226 & 2.376 & & & \\
& Native & 20 & 7.550 & 2.089 & & 49 & 0.699 \\
Flexibility for personal development & ESL & 31 & 7.323 & 2.006 & & & \\
& Native & 20 & 8.3000 & 3.0796 & & 49 & 0.008 \\
& ESL & 31 & 6.3871 & 1.9092 & & & \\
\hline Total score & Native & 20 & 80.5000 & 19.3540 & & 49 & 0.020 \\
& ESL & 31 & 68.4839 & 16.1428 & & \\
\hline
\end{tabular}

Table 7 reveals that there exist notable discrepancies between native and foreign English speaking instructors' instructing methods in favor of native English speaking instructors in their instruction methods in factors 5, 7, and total score.

Table 8. Teachers' gender differences among native and foreign English speaking instructors in their instruction methods

\begin{tabular}{llllllll}
\hline Teaching styles questionnaire & gender & $\mathbf{N}$ & Mean & Std. Deviation & t & df & sig \\
\hline Learner centered activities & Male & 20 & 20.350 & 7.4004 & 0.083 & 49 & 0.934 \\
& female & 31 & 20.516 & 6.6577 & & & \\
Personalizing instruction & Male & 20 & 12.1000 & 3.5229 & 1.932 & 49 & 0.059 \\
& female & 31 & 14.5161 & 4.8157 & & & \\
Relating to experience & Male & 20 & 7.9500 & 2.7429 & 0.021 & 49 & 0.983 \\
& female & 31 & 7.9677 & 3.0603 & & & \\
Assessing student needs & Male & 20 & 7.1000 & 2.4688 & 0.199 & 49 & 0.843 \\
\multirow{5}{*}{ Climate building } & female & 31 & 7.2581 & 2.9436 & & & \\
\multirow{3}{*}{ Participation in the learning process } & Male & 20 & 8.8500 & 2.4554 & 0.468 & 49 & 0.642 \\
& female & 31 & 9.2258 & 2.9968 & & & \\
Flexibility for personal development & 20 & 7.6000 & 2.3709 & 0.530 & 49 & 0.598 \\
& female & 31 & 7.2903 & 1.7925 & & & \\
\hline Total & Male & 20 & 6.4000 & 2.3709 & 1.665 & 49 & 0.102 \\
& female & 31 & 7.6129 & 2.6417 & & & \\
\hline & Male & 20 & 70.3500 & 17.8304 & 0.892 & 49 & 0.377 \\
& female & 31 & 75.0323 & 18.6037 & & & \\
\hline
\end{tabular}

Table 8 shows that there exist no notable discrepancies between male and female instructors in their instruction methods. They have the teaching training workshops.

*** There is positive significant connection between instruction experience and instruction methods $\mathrm{r}=0.532$, $\mathrm{p}<0.01$. This affirmed that teaching experience playing an important role in teaching style. However, teaching experience is not the only factor that effect on teaching style but there are other factors that effect on teaching style such as personality traits, self-efficacy, syllabus, class climate, students' academic levels... etc.

\section{Discussion}

The inclusive goal of the current investigation has been to find out the discrepancies between native and foreign English speaking instructors' teaching styles and their Effect on their students' achievement and enjoyment of learning English registered in an extensive English language plan at the University of Taif. The present research revealed the importance of using native teachers teaching styles that help EFL Saudi students to learn the English language successfully. The findings revealed that there exist notable discrepancies between native and foreign English speaking instructors in the EFL Saudi students' achievement in favor of NESTs. 
This outcome is to some extent in line with the research of Al-Nawrasy (2013) that indicated that there existed a notable correlation between being a native subject and accent in favor of the NESTs and a notable correlation between precision and being a native subject in favor of the NNESTs. Native and foreign English speaking instructors were considered to be various in their language instruction methods. Native English speaking instructors supposed to be much better in instructing advanced reading, speaking and listening courses. At the same time, they were considered to be much better in instructing more colloquial in instructing language or comprehension connected to the social understanding of the target language.

The reason may be because native English instructors are able to convey the significance and advantages of speaking a foreign language and delivering various tactics to enhance learners' acquisition. Such outcomes agree with lots of other outcomes that showed that NESTs were recommended to instruct speaking because of their precise eloquence and accent such as (Al-Omrani, 2008; Arva \& Medgyes, 2000; Lee, 2004; Moussu, 2010; Samimy \& Brutt-Griffler, 1999; Tang, 1997). Although it is not consistent with many of findings, which affirmed that instructors nativeness and former works have no notable influences on the EFL Saudi learners' acquisition processes (e.g., Alghofaili \& Elyas, 2017). Nevertheless, Wardak (2014) obviously shows that NES and NNES instructors are equally competent, and potent to instruct at more advanced levels.

Furthermore, the results declared that there exist discrepancies between the learners of native English speaking instructors and the learners of foreign English speaking instructors for the English learning enjoyment in favor of the students of native English speaking teachers. This could be explained in the light of that foreign English speaking instructors sometimes used some Arabic words, so the student does not feel that he achieve the main goal of learning English to talk in English all time. In addition to, native English speaking teachers use different teaching practices/strategies inside the classroom more non-native. Native English speaking teachers encourage the students to use English language practically. While non-native teachers encourage the students to memorize. Also because native teachers build different channels for communication with their student such as emails, Facebook, chat,... etc. This result agrees with the researches, e.g., Dewaele (1992) and Regan (1996) which found that active interaction with native speakers has the most significant effect and important effect on the acquisition of second language. However, On the contrary the present study Beckett \& Stiefvater (2009) confirm that learners are pleased to learn from NNESTs in classes like presentation talents, math, engineering, and business, particularly from NNESTs that share their social background.

The most striking difference in these data was between men and women in learners in the enjoyment of learning the English language in favor of the males. The findings indicate significant gender discrepancies in the pleasure of acquiring the English language in favor of the males. Such result is consistent with other earlier studies (e.g., Carroll, 2001; Frenzel, Pekrun, \& Goetz, 2007; Siebert, 2003) which reported that boys possessed more positive perceptions of enjoyment than girls. On the contrary, this finding does not get along with the studies of $\mathrm{Al} \mathrm{Shara}$ (2015) and Gorard (2011) which affirm that girls experienced more enjoyment than boys and under 50\% of female noted pleasing schools, in comparison with just above $40 \%$ of male.

Regarding the gender discrepancies between male and female teachers, this study sees no differences among them. Similarly this result agrees with the study of Starbuck (2003). However, this study is contradicted with many former studies that examined teaching styles and discovered that the methods of men and women faculty differed (Kuh, Nelson Laird, \& Umbach, 2004; Lacey, Saleh, \& Gorman, 1998; Statham, Richardson, \& Cook, 1991).

Regards to the influence of instruction experience on teacher efficacy, this study affirmed that teaching experience playing an important role in teaching style. Such this finding agrees with the study of Hebert, Lee, \& Williamson (1998) that found a discrepancy between novice and experienced instructors.

\section{Conclusion}

The purpose of this research was to analyze differences between native and foreign English speaking instructors' methods and styles and their Effect on their students' achievement and enjoyment of learning English. The outcomes of the present research supported the native English speaking instructors in their teaching styles and the students' achievement and enjoyment. The outcomes of the research also depicted that there exist gender discrepancies for the Enjoyment of acquisition. It means that men graded better than women for the pleasure of learning. This study can contribute to reducing gender difference regarding students' enjoyment toward learning English in Saudi Arabia by ensuring that all students are encouraged to motivate and participate in learning English. Paying more attention to the conditions of study in the university through building a suitable and enjoyable environment can help students to achieve more.

Although the outcomes of the current research may not be generalized to all native and foreign English subjects, 
however they provide insights into the general view of native and foreign English subjects instruction styles and their effects on their students' achievement. The small size of the sample constitutes another limitation of the study. Using only thirty five native and non-native EFL teachers might not be representative enough to second language generalize the findings of the research to the entire native and non-native EFL teachers who might have other ways of teaching their classes that the study did not address.

Future studies could investigate teaching styles in secondary instruction so as to assess the efficacy of the styles suggested by this study for practicing teachers. In so doing, they could bring improvement in what did not work and share the findings with teachers from other places.

\section{References}

Ainley, M., \& John, A. (2011). Student engagement with science in early adolescence: The contribution of enjoyment to students' continuing interest in learning about science. Contemporary Educational Psychology, Suppl. Students' Emotions and Academic Engagement, 36(1), 4-12. http://dx.doi.org/10.1016/j.cedpsych.2010.08.001

Alghofaili, N. M., \& Elyas, T. (2017). Decoding the Myths of the Native and Non-Native English Speakers Teachers (NESTs \& NNESTs) on Saudi EFL Tertiary Students. English Language Teaching, 10(6), 1-11. http://dx.doi.org/10.1016/j.cedpsych.2010.08.001

Al-Nawrasy, O. (2013). The Effect of Native and Nonnative English Language Teachers on Secondary Students' Achievement in Speaking Skills. Jordan Journal of Educational Sciences, 9(2), 243-254.

Al-Omrani, A. H. (2008). Perceptions and attitudes of Saudi ESL and EFL students toward native and nonnative English-speaking teachers. ProQuest.

Al-Shara, I. (2015). Learning and Teaching between Enjoyment and Boredom as Realized by the Students: A Survey from the Educational Field. European Scientific Journal, 11(19), 146-168.

Arva, V., \& Medgyes, P. (2000). Native and Non-native Teachers in the Classroom. System, 28(3), 355-372. http://doi.org/10.1177/2158244014534451

Beckett, G. H., \& Stiefvater, A. (2009). Change in ESL graduate students' perspectives on non-native English-speaker teachers. TESL Canada Journal, 27(1), 27-46. https://doi.org/10.18806/tesl.v27i1.1028

Carroll, B. L. (2001). Children's perceived competence and enjoyment in physical education and physical activity outside school. European Physical Education Review, 7, 24-43. https://doi.org/10.1177/1356336X010071005

Clements, D. (1995). Playing with computers, playing with ideas. In Educational Psychology Review, 7(2), 203-207. http://doi.org/10.1007/BF02212494

Conti, G. (1989). Assessing teaching style in continuing education. In E. R. Hayes (Ed.), Effective teaching styles (pp. 87-91). San Francisco: Jossey-Bass Publishers. https://doi.org/10.1002/ace.36719894303

Davis, W. (1982). A causal theory of enjoyment. In Proceedings of Mind 91, XCI Press, 240-256. https://doi.org/10.1093/mind/xci.362.240

Dewaele, J. M. (1992). L'omission du ne dans deux styles oraux d'interlangue française. Interface: Journal of Applied Linguistics, 7(1), 3-17.

Frenzel, A. C., Pekrun, R., \& Goetz, T. (2007). Girls and mathematics-A "hopeless" issue? A control-value approach to gender differences in emotions towards mathematics. European Journal of Psychology of Education, 22, 497-514. https://doi.org/10.1007/BF03173468

Gorard, S. S. (2011). How can we enhance enjoyment of secondary school? The student view. British Educational Research Journal, 37, 671-690. https://doi.org/10.1080/01411926.2010.488718

Herbert, E., Lee, A., \& Williamson, L. (1998). Teachers' and Teacher Education Students' Sense of Efficacy: Quantitative and Qualitative Comparisons. Journal of Research and Development in Education, 31(4), 214-225.

Heidegger, M. (1990). Being and Time. (Q. Macquarrie \& E. Robinson, Trans.). Oxford: Blackwell,

Knowles, M. S. (1970). The modern practice of adult education: Andragogy versus pedagogy. New York: Association Press.

Kremer, J., Trew, K., \& Ogle, S. (1997). Young People's Involvement in Sport. London: Routledge. 
Kuh, G. D., Nelson Laird, T. F., \& Umbach, P. D. (2004). Aligning faculty and student behavior: Realizing the promise of Greater Expectations. Liberal Education, 90(4), 24-31.

Kunter, M., Tsai, Y. M., Klusmann, U., Brunner, M., Krauss, S., \& Baumert, J. (2008). Students' and mathematics teachers' perceptions of teacher enthusiasm and instruction. Learning and Instruction, 18, 468-482. http://doi.org/10.1016/j.learninstruc.2008.06.008

Kuppens, P. (2008). Individual differences in the relationship between pleasure and arousal. Journal of Research in Personality, 42, 1053-1059. http://doi.org/10.1016/j.jrp.2007.10.007

Lacey, C. H., Saleh, A., \& Gorman, R. (1998). Teaching nine to five: A study of the teaching styles of male and female professors. Paper presented at the Annual Women in Education Conference, Lincoln, Nebraska, October 11-12.

Lee, I. (2004). Preparing nonnative English speakers for EFL teaching in Hong Kong. In Kamhi-Stein (Ed.), Learning and Teaching from Experience (pp. 230-250). Ann Arbor, MI: University of Michigan Press.

Mahboob, A. (2004). Native or nonnative: What do students enrolled in an intensive English program think? In L. D. Kamhi-Stein (Ed.), Learning and teaching from experience (pp. 121-148). Ann Arbor, MI: University of Michigan Press.

Malone, T. W. (1980). What makes things fun to learn? Heuristics for designing instructional computer games. In Proceedings of the 3rd ACM SIGSMAEL Symposium and the First SIGPC Symposium on Small Systems. Palo Alto, California, United States, SIGSMALL '80. ACM, New York, NY, 162-169. https://doi.org/10.1145/800088.802839

Medgyes, P. (1994). The non-native teacher. London: Macmillan. Walkinshaw, and Duong.

Montessori, M. M. (1965). Spontaneous Activity in Education: The Advanced Montessori Method. New York: John Wiley.

Moussu, L. (2010). Influence of teacher-contact time and other variables on ESL students' attitudes towards native- and non-native-English-speaking teachers. TESOL Quarterly, 44, 746-768. http://doi.org/10.2307/27896762

Pekrun, R., Goetz, T., \& Derry, R. P. (2005). Achievement Emotions Questionnaire (AEQ), User's Manual. Department of Psychology, Munich University.

Phillipson, R. (1992). ELT: The native speaker's burden? ELT Journal, 46(1), 12-18. https://doi.org/10.1093/elt/46.1.12

Piaget, J. (1962). Play, dreams and imitation in childhood. New York: Norton.

Prensky, M. F. (2001). Play and Games: What Makes Games Engaging. In Digital game-based learning. Comput. Entertain.

Regan, V. (1996). Variation in French interlanguage: A longitudinal study of sociolinguistic competence. In R. Bayley \& D. Preston (Eds.), Second Language Acquisition and Linguistic Variation (pp. 177-201). Amsterdam and Philadelphia: Benjamins. https://doi.org/10.1075/sibil.10.08reg

Resnick, M., Bruckman, A., \& Martin, F. (1999). Constructional Design: Creating New Construction Kits for Kids. In A. Druin (Ed.), The Design of Children's Technology. San Francisco, USA: Morgan Rauffman.

Richards, J., Platt, J., \& Platt, H. (1992). Language Dictionary of Language Teaching and Applied Linguistics. Harlow: Longman.

Samimy, K. K., \& Brutt-Griffler, J. (1999). To Be a Native Speaker: Perceptions of "Non-Native" Students in a Graduate TESOL Program. In G. Braine (Eds.), Non-native educators in English language teaching, 127-145. Mahwah, NJ: Lawrence Erlbaum Associates, Inc.

Scherer, K. R. (1986). Vocal affect expression: A review and a model for future research. Psychological Bulletin, 99, 143-156. https://doi.org/10.1037/0033-2909.99.2.143

Siebert, L. L. (2003). Student and teacher beliefs about language learning. The ORTESOL Journal, 21, 7-39.

Starbuck, G. H. (2003). College teaching styles by gender. Paper presented at the Western Social Science Association Annual Meeting, Las Vegas, NV, April 9-12.

Statham, A., Richardson, L., \& Cook, J. A. (1991).Gender and university teaching: A negotiated difference. Albany: State University of New York Press. 
Walkinshaw, I., \& Oanh, D. H. (2014). Native and non-native English language teachers: Student perceptions in Vietnam and Japan. Thousand Oaks: SAGE publication. http://doi.org/10.1177/2158244014534451

Wankel, L. M. (1993). The Importance of Enjoyment to Adherence and Psychological Benefits from Physical Activity. Proceedings of International Journal of Sport Psychology 2A, 151-169.

Wardak, M. (2014). Native and Non-Native English Speaking Teachers' Advantages and Disadvantages. Arab World English Journal, 5(3), 124-141.

\section{Appendix A.}

\section{Principles of Adult Learning Scale}

\section{Dear colleague,}

The following survey contains several things that a teacher of University students might do in a classroom. You may personally find some of them desirable and find others undesirable. For each item please respond to the way you most frequently practice the action described in the item. Your choices are Always, Almost Always, Often, Seldom, Almost Never, and Never. If the item does not apply to you, select Never.

Thank you for taking the time to assist me in this research

Age

Gender

Place of Birth

Years of teaching experiences (How many)

PYP morning Group number

Highest Degree Held

\begin{tabular}{|c|c|c|c|c|c|c|c|}
\hline $\begin{array}{l}\text { No. } \\
\text { items }\end{array}$ & Items & 莣 & 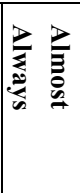 & $\stackrel{0}{\stackrel{0}{g}}$ & $\begin{array}{l}\mathscr{\alpha} \\
\frac{\alpha}{2} \\
\stackrel{\theta}{E}\end{array}$ & 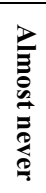 & $\begin{array}{l}Z \\
9 \\
9 \\
9\end{array}$ \\
\hline & 1. Learner centered activities & & & & & & \\
\hline 1 & $\begin{array}{l}\text { I allow students to participate in developing the criteria for evaluating } \\
\text { their performance in class. }\end{array}$ & 1 & 2 & 3 & 4 & 5 & 6 \\
\hline 2 & I use disciplinary action when it is needed. & 1 & 2 & 3 & 4 & 5 & 6 \\
\hline 3 & $\begin{array}{l}\text { I allow my students more time to complete assignments when they need } \\
\text { it. }\end{array}$ & 1 & 2 & 3 & 4 & 5 & 6 \\
\hline 4 & I encourage students to adopt middle-class values. & 1 & 2 & 3 & 4 & 5 & 6 \\
\hline 5 & $\begin{array}{l}\text { I help students diagnose the gaps between their goals and their present } \\
\text { level of performance. }\end{array}$ & 1 & 2 & 3 & 4 & 5 & 6 \\
\hline 6 & I provide knowledge rather than serve as a resource person. & 1 & 2 & 3 & 4 & 5 & 6 \\
\hline 7 & $\begin{array}{l}\text { I stick to the instructional objectives that I write at the beginning of a } \\
\text { program. }\end{array}$ & 1 & 2 & 3 & 4 & 5 & 6 \\
\hline 8 & I participate in the informal counseling of students. & 1 & 2 & 3 & 4 & 5 & 6 \\
\hline 9 & $\begin{array}{l}\text { I use lecturing as the best method for presenting my subject material to } \\
\text { the students. }\end{array}$ & 1 & 2 & 3 & 4 & 5 & 6 \\
\hline 10 & I arrange the classroom so that it is easy for students to interact. & 1 & 2 & 3 & 4 & 5 & 6 \\
\hline 11 & I determine the educational objectives for each of my students. & 1 & 2 & 3 & 4 & 5 & 6 \\
\hline \multirow[t]{2}{*}{12} & $\begin{array}{l}\text { I plan units which differ as widely as possible from my students' } \\
\text { socio-economic backgrounds. }\end{array}$ & 1 & 2 & 3 & 4 & 5 & 6 \\
\hline & 2. Personalizing instruction & & & & & & \\
\hline 13 & $\begin{array}{l}\text { I get a student to motivate himself/ herself by confronting him/her in the } \\
\text { presence of classmates during group discussions. }\end{array}$ & 1 & 2 & 3 & 4 & 5 & 6 \\
\hline 14 & $\begin{array}{l}\text { I plan learning episodes to take into account my students' prior } \\
\text { experiences. }\end{array}$ & 1 & 2 & 3 & 4 & 5 & 6 \\
\hline 15 & $\begin{array}{l}\text { I allow students to participate in making decisions about the topics that } \\
\text { will be covered in class. }\end{array}$ & 1 & 2 & 3 & 4 & 5 & 6 \\
\hline
\end{tabular}




\begin{tabular}{|c|c|c|c|c|c|c|c|}
\hline 16 & $\begin{array}{l}\text { I use one basic teaching method because I have found that most adults } \\
\text { have a similar style of learning. }\end{array}$ & 1 & 2 & 3 & 4 & 5 & 6 \\
\hline 17 & I use different techniques depending on the students being taught. & 1 & 2 & 3 & 4 & 5 & 6 \\
\hline 18 & I encourage dialogue among my students. & 1 & 2 & 3 & 4 & 5 & 6 \\
\hline 19 & $\begin{array}{l}\text { I use written tests to assess the degree of academic growth in learning } \\
\text { rather than to indicate new directions for learning. }\end{array}$ & 1 & 2 & 3 & 4 & 5 & 6 \\
\hline 20 & $\begin{array}{l}\text { I utilize the many competencies that most students already possess to } \\
\text { achieve educational objectives. }\end{array}$ & 1 & 2 & 3 & 4 & 5 & 6 \\
\hline \multirow[t]{2}{*}{21} & $\begin{array}{l}\text { I use what history has proven that students need to learn as my chief } \\
\text { criteria for planning learning episodes. }\end{array}$ & 1 & 2 & 3 & 4 & 5 & 6 \\
\hline & 3. Relating to experience & & & & & & \\
\hline 22 & I accept errors as a natural part of the learning process. & 1 & 2 & 3 & 4 & 5 & 6 \\
\hline 23 & $\begin{array}{l}\text { I have individual conferences to help students identify their educational } \\
\text { needs. }\end{array}$ & 1 & 2 & 3 & 4 & 5 & 6 \\
\hline 24 & $\begin{array}{l}\text { I let each student work at his/her own rate regardless of the amount of } \\
\text { time it takes him/her to learn a new concept. }\end{array}$ & 1 & 2 & 3 & 4 & 5 & 6 \\
\hline 25 & I help my students develop short-range as well as long-range objectives. & 1 & 2 & 3 & 4 & 5 & 6 \\
\hline 26 & $\begin{array}{l}\text { I maintain a well-disciplined classroom to reduce interferences to } \\
\text { learning. }\end{array}$ & 1 & 2 & 3 & 4 & 5 & 6 \\
\hline \multirow[t]{2}{*}{27} & I avoid discussion of controversial subjects that involve value judgments. & 1 & 2 & 3 & 4 & 5 & 6 \\
\hline & 4. Assessing student needs & & & & & & \\
\hline 28 & I allow my students to take periodic breaks during the class. & 1 & 2 & 3 & 4 & 5 & 6 \\
\hline 29 & I use methods that foster quiet, productive, deskwork. & 1 & 2 & 3 & 4 & 5 & 6 \\
\hline 30 & I use tests as my chief method of evaluating students. & 1 & 2 & 3 & 4 & 5 & 6 \\
\hline \multirow[t]{2}{*}{31} & $\begin{array}{l}\text { I plan activities that will encourage each student's growth from } \\
\text { dependence on others to greater independence. }\end{array}$ & 1 & 2 & 3 & 4 & 5 & 6 \\
\hline & 5. Climate building & & & & & & \\
\hline 32 & $\begin{array}{l}\text { I gear my instructional objectives to match the individual abilities and } \\
\text { needs of the students. }\end{array}$ & 1 & 2 & 3 & 4 & 5 & 6 \\
\hline 33 & I avoid issues that relate to the student's concept of himself/herself. & 1 & 2 & 3 & 4 & 5 & 6 \\
\hline 34 & I encourage my students to ask questions about the nature of their society. & 1 & 2 & 3 & 4 & 5 & 6 \\
\hline \multirow[t]{2}{*}{35} & $\begin{array}{l}\text { I allow a student's motives for participating in continuing education to be } \\
\text { a major determinant in the planning of learning objectives. }\end{array}$ & 1 & 2 & 3 & 4 & 5 & 6 \\
\hline & 6. Participation in the learning process & & & & & & \\
\hline 36 & I have my students identify their own problems that need to be solved. & 1 & 2 & 3 & 4 & 5 & 6 \\
\hline 37 & I give all students in my class the same assignment on a given topic. & 1 & 2 & 3 & 4 & 5 & 6 \\
\hline 38 & I use materials that were originally designed for students in university. & 1 & 2 & 3 & 4 & 5 & 6 \\
\hline \multirow[t]{2}{*}{39} & $\begin{array}{l}\text { I organize adult learning episodes according to the problems that my } \\
\text { students encounter in everyday life. }\end{array}$ & 1 & 2 & 3 & 4 & 5 & 6 \\
\hline & 7. Flexibility for personal development & & & & & & \\
\hline 40 & $\begin{array}{l}\text { I measure a student's long-term educational growth by comparing his/her } \\
\text { total achievement in class to his/her expected performance as measured } \\
\text { by national norms from standardized tests. }\end{array}$ & 1 & 2 & 3 & 4 & 5 & 6 \\
\hline 41 & I encourage competition among my students. & 1 & 2 & 3 & 4 & 5 & 6 \\
\hline 42 & I use different materials with different students. & 1 & 2 & 3 & 4 & 5 & 6 \\
\hline 43 & I help students relate new learning to their prior experiences. & 1 & 2 & 3 & 4 & 5 & 6 \\
\hline 44 & I teach units about problems of everyday living. & 1 & 2 & 3 & 4 & 5 & 6 \\
\hline
\end{tabular}




\section{Appendix B.}

\section{Learning English Enjoyment Questionnaire (LEEQ)}

First version of Learning English Enjoyment questionnaire

\begin{tabular}{|c|c|c|c|c|c|c|}
\hline $\begin{array}{l}\text { No. } \\
\text { items }\end{array}$ & Items & 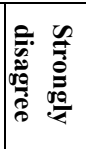 & 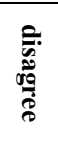 & 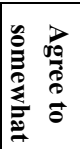 & $\frac{b_{0}}{8}$ & 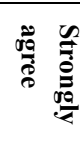 \\
\hline 1 & I look forward to studying English. & 1 & 2 & 3 & 4 & 5 \\
\hline 2 & I enjoy the challenge of learning the English material. & 1 & 2 & 3 & 4 & 5 \\
\hline 3 & I enjoy acquiring new knowledge. & 1 & 2 & 3 & 4 & 5 \\
\hline 4 & I enjoy dealing with English course material. & 1 & 2 & 3 & 4 & 5 \\
\hline 5 & Reflecting on my progress in my English coursework makes me happy. & 1 & 2 & 3 & 4 & 5 \\
\hline 6 & I study more than required because I enjoy studying English very much. & 1 & 2 & 3 & 4 & 5 \\
\hline 7 & $\begin{array}{l}\text { I am very happy about the progress I have made, so I am motivated to } \\
\text { continue studying English. }\end{array}$ & 1 & 2 & 3 & 4 & 5 \\
\hline 8 & $\begin{array}{l}\text { Certain English subjects are so enjoyable that I am motivated to do extra } \\
\text { reading about them. }\end{array}$ & 1 & 2 & 3 & 4 & 5 \\
\hline 9 & When my studies are going well, it gives me a "rush". & 1 & 2 & 3 & 4 & 5 \\
\hline 10 & I become physically excited when my studies are going well. & 1 & 2 & 3 & 4 & 5 \\
\hline 11 & I enjoy being in the English class. & 1 & 2 & 3 & 4 & 5 \\
\hline 12 & I enjoy doing English activities. & 1 & 2 & 3 & 4 & 5 \\
\hline 13 & I enjoy learning English. & 1 & 2 & 3 & 4 & 5 \\
\hline 14 & I enjoy listening to English. & 1 & 2 & 3 & 4 & 5 \\
\hline 15 & I enjoy participating in the English class. & 1 & 2 & 3 & 4 & 5 \\
\hline 16 & I enjoy talking English with the English native speakers. & 1 & 2 & 3 & 4 & 5 \\
\hline 17 & I enjoy reading English short stories. & 1 & 2 & 3 & 4 & 5 \\
\hline 18 & I enjoy my interaction with my teacher in English. & 1 & 2 & 3 & 4 & 5 \\
\hline 19 & $\begin{array}{l}\text { I enjoy benefiting from my teacher's sharing of her unique information } \\
\text { and experiences. }\end{array}$ & 1 & 2 & 3 & 4 & 5 \\
\hline 20 & I enjoy participating in group work in English lectures. & 1 & 2 & 3 & 4 & 5 \\
\hline 21 & I enjoy helping other students in the English course. & 1 & 2 & 3 & 4 & 5 \\
\hline 22 & I enjoy preparing for the English lessons before attending the class. & 1 & 2 & 3 & 4 & 5 \\
\hline 23 & I enjoy studying with my classmates for English exams. & 1 & 2 & 3 & 4 & 5 \\
\hline 24 & I enjoy acquiring useful English expressions from my English teacher. & 1 & 2 & 3 & 4 & 5 \\
\hline 25 & I enjoy making a note of useful English expressions. & 1 & 2 & 3 & 4 & 5 \\
\hline 26 & $\begin{array}{l}\text { When my teacher includes various forms of technology, I enjoy learning } \\
\text { English more. }\end{array}$ & 1 & 2 & 3 & 4 & 5 \\
\hline
\end{tabular}

\section{Learning English Enjoyment questionnaire}

Extraction Method: Principal Component Analysis. Rotation Method: Equamax with Kaiser Normalization. A Rotation converged in 14 iterations.

Table 1. Factor analyses: learning English enjoyment questionnaire

\begin{tabular}{lllll}
\hline Factor & Description & Eigen value & \% of variance & Cumulative \% \\
\hline 1 & Enjoying to acquire new knowledge in English & 3.896 & 17.710 & 17.710 \\
2 & Motivational aspects/ affectional aspects & 3.422 & 15.554 & 33.264 \\
3 & Enjoying participating/ group work in English & 3.139 & 14.266 & 47.531 \\
4 & Enjoy doing English activities in the classroom. & 3.135 & 14.251 & 61.781 \\
\hline
\end{tabular}

Table 3. Dimension-total correlations between dimensions and total score for learning English enjoyment questionnaire subscales

\begin{tabular}{lrlll}
\hline Sub factors & Factor 1 & Factor 2 & Factor 3 & Factor 4 \\
\hline Correlations & $0.810^{* *}$ & $0.878^{* *}$ & $0.744^{* *}$ & $0.858^{* *}$ \\
\hline Note. & $* *$ Correlation is significant at the $p<0.01$. & & &
\end{tabular}




\section{Final version of learning English enjoyment questionnaire}

\begin{tabular}{|c|c|c|c|c|c|c|c|}
\hline $\begin{array}{l}\text { No. } \\
\text { items }\end{array}$ & Items & 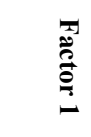 & 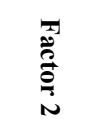 & 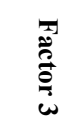 & $\begin{array}{l}\text { गै } \\
\stackrel{0}{0} \\
\stackrel{0}{0} \\
+\end{array}$ & $\begin{array}{l}\frac{3}{8} \\
\stackrel{3}{\Xi}\end{array}$ & $\bumpeq$ \\
\hline & Enjoying to acquire new knowledge in English & & & & & & \\
\hline 1 & I look forward to studying English. & 0.818 & & & & 4.2857 & .7420 \\
\hline 2 & I enjoy the challenge of learning the English material. & 0.792 & & & & 3.7857 & .9509 \\
\hline 3 & $\begin{array}{l}\text { I enjoy acquiring new knowledge about the English } \\
\text { language/in English. }\end{array}$ & 0.701 & & & & 4.2857 & .7420 \\
\hline 5 & $\begin{array}{l}\text { Reflecting on my progress in my English coursework } \\
\text { makes me happy. }\end{array}$ & 0.357 & & & & 4.4762 & .8036 \\
\hline 13 & I enjoy learning English. & 0.597 & & & & 4.0952 & .8782 \\
\hline 14 & I enjoy listening to English. & 0.548 & & & & 3.5238 & 1.0178 \\
\hline \multirow[t]{2}{*}{17} & I enjoy reading English short stories. & 0.398 & & & & 3.3810 & 1.1252 \\
\hline & Motivational aspects/ affectional aspects & & & & & & \\
\hline 6 & $\begin{array}{l}\text { I study more than required because I enjoy studying } \\
\text { English very much. }\end{array}$ & & 0.367 & & & 3.0952 & 1.0075 \\
\hline 7 & $\begin{array}{l}\text { I am very happy about the progress I have made, so I am } \\
\text { motivated to continue studying English. }\end{array}$ & & 0.617 & & & 3.7857 & .9762 \\
\hline 8 & $\begin{array}{l}\text { Certain English subjects are so enjoyable that I am } \\
\text { motivated to do extra reading about them. }\end{array}$ & & 0.422 & & & 3.4524 & 1.1306 \\
\hline \multirow[t]{2}{*}{25} & I enjoy making a note of useful English expressions. & & 0.772 & & & 3.8810 & 1.1935 \\
\hline & Enjoying participation in English & & & & & & \\
\hline 15 & I enjoy participating in the English class. & & & 0.585 & & 3.5714 & 1.0393 \\
\hline 20 & I enjoy participating in group work in English lectures. & & & 0.707 & & 3.8810 & 1.0170 \\
\hline 21 & I enjoy helping other students in the English course. & & & .0874 & & 4.1905 & 1.0415 \\
\hline 23 & I enjoy studying with my classmates for English exams. & & & 0.461 & & 3.5952 & 1.2699 \\
\hline \multirow[t]{2}{*}{26} & $\begin{array}{l}\text { When my teacher includes various forms of technology, I } \\
\text { enjoy learning English more. }\end{array}$ & & & 0.569 & & 3.2381 & 1.1001 \\
\hline & Enjoy doing English activities in the classroom & & & & & & \\
\hline 12 & I enjoy doing English activities in the classroom. & & & & 0.369 & 3.2857 & 1.0190 \\
\hline 16 & $\begin{array}{l}\text { I enjoy speaking in English with the English native } \\
\text { teacher. }\end{array}$ & & & & 0.620 & 3.5714 & 1.1717 \\
\hline 24 & $\begin{array}{l}\text { I enjoy acquiring useful English expressions from my } \\
\text { English teacher. }\end{array}$ & & & & 0.369 & 3.5952 & 1.2699 \\
\hline 22 & $\begin{array}{l}\text { I enjoy preparing for the English lessons before attending } \\
\text { the class. }\end{array}$ & & & & 0.625 & 3.3810 & 1.3058 \\
\hline
\end{tabular}

\section{Copyrights}

Copyright for this article is retained by the author(s), with first publication rights granted to the journal.

This is an open-access article distributed under the terms and conditions of the Creative Commons Attribution license (http://creativecommons.org/licenses/by/4.0/). 